\title{
Team Players and Team Managers: Special Educators Working with Paraeducators to Support Inclusive Classrooms
}

\author{
Betty Y. Ashbaker ${ }^{1}$, Jill Morgan ${ }^{2}$ \\ ${ }^{1}$ Counseling Psychology \& Special Education, Brigham Young University, Provo, USA \\ ${ }^{2}$ School of Education, Swansea Metropolitan University, Swansea, UK \\ Email: betty_ashbaker@byu.edu, jill.morgan@smu.ac.uk
}

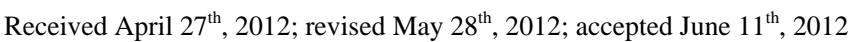

\begin{abstract}
This paper summarizes recommendations from a selection of international research literature urging teachers to take the initiative in their own classrooms to invite paraeducators to participate fully as team players in collaborative work. In US classrooms paraeducators (teacher aides/teacher assistants) have long been making valuable contributions in providing education services to students with a variety of needs. The literature documents change in their roles. Legislation has influenced their required qualifications - although legislation still refers to them as paraprofessionals. While some researchers have cast doubt on whether paraeducators are truly effective in their assigned roles, others have warned that the education system is over-reliant on them. In response to this changing perspective, teacher educators must revise programs to better prepare teacher candidates to effectively team with paraeducators. Personnel developers and school administrators must provide inservice training for a generation of teachers who have received little if any training in this area.
\end{abstract}

Keywords: Paraeducators; Paraprofessionals; Inclusion; Team Players; Managers

\section{Introduction}

Paraeducators have become increasingly important in the U.S. public education system. In the 2003-2004 school year, 91 percent of public schools reported employing at least one paraeducator (NCES, 2007). A national change began when the No Child Left Behind (NCLB) Act specifically defined the title paraprofessional (paraeducator) and specified the responsibilities and the limitations for instructional paraprofessionals employed by each Local Educational Agency (LEA) in a program supported with funds under the Act. A portion of IDEIA (2004) federal money is also spent each year to provide the services of paraprofessionals to assist children with disabilities, and today most US public schools have paraeducators employed as support staff responsible for assisting in the delivery of instruction (Hoffman \& Sable, 2006).

In this article, we draw on the international literature relating to paraeducators and offer a précis of the recommendations which have been made regarding their employment, professsional development and supervision, emphasizing the necessity of each teacher taking the initiative in his or her own classroom to develop an effective instructional team. We draw on literature from a variety of different countries, where titles assigned to paraeducators vary: Teaching Assistants (TAs) in the United Kingdom, Special Needs Assistants (SNAs) in the Republic of Ireland, teacher aides in Australia, and classroom assistants in Finland. For convenience, in this article we refer to them all as paraeducators. First, we discuss the literature on roles of paraeducators; then we cluster the literature into several themes: clarifying roles/expectations, monitoring the support that paraeducators provide, and providing on-the-job training for para- educators—commenting briefly on each.

\section{Roles and Challenges of Paraeducators}

When paraeducators were first introduced into classrooms, their main role was to support the teacher in clerical work, but over time this role has changed significantly. Formerly, their duties typically consisted of taking attendance, checking papers, preparing materials/bulletin boards, and other clerical or housekeeping duties (Blalock, 1991; French, 1999); now this workforce is engaged in many other important tasks more directly linked with teaching and learning.

\section{Role Variety}

Paraeducators are often found in self-contained classes, resource rooms, and general education classrooms (where they bridge inclusion activities). The specifics of their roles are determined by the needs of the students they serve. Rueda and Monzo (2002) identified five major roles of the paraeducator: instructional, school support, liaison, personal support, and oneto-one class support-this latter role being the most common. Broer et al. (2005) found that students with intellectual disabilities viewed paraeducators as having various roles such as "mother", friend, protector, and primary teacher. Chopra et al. (2004) suggest that paraeducators could also assume the role of connector: connecting parents to teachers; parents to community services; students to teachers, parents, peers, and-not least - to the curriculum. Hauge and Babkie (2006) likewise identify the special relationships that often develop between paraeducators and the children they support, as well as their 
families.

Among the multiple roles of paraeducators, Kerry and Kerry (2003) report that among ethnic groups in the Czech Republic paraeducators help in overcoming the language and cultural barriers that young traveller children can face when they first enter school. Similarly, US findings show that Latino paraeducators hired from among the ethnic community use a number of strategies to help ELL and bilingual students create new linguistic, cultural, and academic context in schools, while providing a role model from within the minority culture (Center for Research on Education, 2000; Rueda \& Monzó, 2000).

Allen and Ashbaker (2004) have recommended that paraeducators serve on school-based crisis prevention and intervention teams. They are of course already extensively involved in supporting the development of students' literacy skills (CaustonTheoharis, 2007; Cobb, 2007); and they have developed significant roles in the relatively recent RTI initiative (Hauerwas \& Goessling, 2008). Blair (2002) reports that many programs recruit future special educators from dedicated, experienced paraeducators, considering them promising future teachers representing minority cultures and backgrounds (Gursky, 2002).

As part of both the inclusive practice movement and the development of new service delivery models in recent decades, paraeducators and those who hire them are becoming more aware of the pivotal role they play. Federal legislation now requires higher levels of qualifications for paraeducators working in Title I programs (NCLB (2001) specifies two years of college or state-determined tests of competence), and IDEA (2004) requires that they be "appropriately trained and supervised" in order to work with students with disabilities (Cortese, 2005). Paraeducators are now considered by many as key to the delivery of special education and related services (Giangreco \& Doyle, 2002; Hughes \& Valle-Riestra, 2008). Blacher and Rodriguez (2007) list multiple advantages of hiring paraeducators to support the delivery of special education services in both academic skills development and social/behavioral intervenetions.

\section{Potential Difficulties}

With the increasingly wide variety in the roles undertaken by paraeducators, Giangreco and Broer (2007) and Giangreco et al. (2011) warn against the education system becoming over-reliant on their support. Giangreco (2003) notes that "sometimes relying on paraeducators may feel effective because it relieves, distributes or shifts responsibility for educating a student with specialized needs, but educators should not confuse this outcome with effectiveness for students" (p. 50).

Giangreco and colleagues are not alone in expressing concerns over whether the support provided by paraeducators can be considered universally effective with student progress and achievement. Research in the United Kingdom (Roberts, 2010) suggests that although the presence of a paraeducator in the classroom may reduce teacher workload and stress, there is evidence to suggest that students who receive support from a paraeducator may make less progress than similar peers who receive no support. In fact, Roberts (2010) documents instances revealing a negative correlation between support and student achievement.

McGrath et al. (2010) offer one explanation for such a correlation:

"The problem becomes evident when the student with special needs begins to spend most of his or her social time (lunch, recess) with the paraeducator and not with peers or when the paraeducator begins to make most curricular and instructional decisions for the student” (p. 2).

This highlights both social and educational disadvantages students may experience as the paraeducator who is provided to enable students to function in an inclusive classroom isolates them both from their peers and from the professional who is specifically trained to make the decisions about their specialized needs.

Additionally, Patterson (2006) and others have documented the high levels of freedom and independence many paraeducators experience in their work-terms which may be considered synonymous with unsupervised in this context. Ashbaker and Morgan (2004) and more recently Darden (2009) have warned of potential legal issues when students with disabilities are assigned to paraeducators for large portions of the day, documenting legal cases and appeals under both special education and civil rights legislation.

Walsh and Jones (2004) recommend that paraeducators participate in co-teaching situations with general education teachers if the number of special educators in a school is insufficient to allow for co-teaching between professionals. While this may appear to be a logical and practical solution, particularly in small schools and districts, these researchers also warn of several "significant challenges" inherent in this approach:

"Schools and districts must provide ongoing staff development and supervision for paraeducators... and parents may question the ability of a paraeducator to provide direct support to students with disabilities in the absence of direct supervision by the special education teacher. Special education teachers involved with this model must understand their responsibility to supervise and monitor... all students on their caseload, including students served by the paraeducator" (Walsh \& Jones, 2004: p. 19).

All of these challenges relate to the paraeducator working independently of the teacher rather than-as legislation requires-working "under the direct supervision of a professsional” (NCLB, 2001) or being “adequately supervised” (IDEA, 2004).

\section{Training Issues}

\section{Training for Teachers}

Many have pointed out the need for special educators to receive training in how to work advantageously with paraeducators (Allen et al., 1996; French, 2001; Morgan \& Ashbaker, 2001; Pickett, 2002). Kerry and Kerry (2003) report from the United Kingdom that paraeducators themselves have recommended that their supervising teachers receive training in how to work more effectively with them. But little progress has been noted in this area to date (DeFries, 2010; Lewis \& McKenzie, 2009).

Causton-Theoharis et al. (2007) and Mastropieri (2001) report that collaborating with other adults is one of the major challenges faced by first-year teachers. Calder and Grieve (2004) suggest some reasons why teachers lack skills in this area. In addition to the absence of training in their teacher preparation programs concerning this aspect of their role (see Carnahan et al., 2009), research suggests that the main influence on teachers' approach to their work is the way they themselves were taught in school. Although paraeducators have been part of the education system for decades, it is likely that there 
were few paraeducators in the classrooms where many of our current teachers were educated. Even recent graduates of teacher training programs are unlikely to have had significant contact with paraeducators, as most of them were in the portion of their mainstream class not requiring support. In addition, the group of professionals least likely to have worked or studied in classrooms with paraeducators are teacher educators (Carnahan et al., 2009). As Calder and Grieve (2004) speculate, "[T]heir mental picture of teaching is unlikely to include a supporting adult” (p. 115). In essence the effective involvement of paraeducators is not necessarily seen by this generation of teachers and their professors as an integral part of "teacher" as a role.

\section{Training for Paraeducators}

We would suggest that the situation is not helped by the sporadic nature of training available to paraeducators. While NCLB requires college-level training, this does not have to be in the field of education (although that is recommended). In addition, this requirement applies only to paraeducators hired under Title I funds (or working in schools designated as Title I schoolwide programs). The IDEA requirement for "appropriate" training has no definition and therefore no teeth. Thus although these items of legislation have been regarded as a step in the right direction, many paraeducators still receive only minimal training - and possibly none-in how to work under the direction of a professional.

\section{Recommendations for Teacher-Paraeducator Collaboration}

Over the past two decades, a large number of researchers and teacher educators have made recommendations for ways teachers can work more effectively with paraeducators. Several common themes have emerged, including some points that might be viewed as general consensus on effective practice. Recommendations from the literature cluster into several themes: clarifying roles/expectations, monitoring the support that paraeducators provide, and providing on-the-job training for paraeducators. We comment briefly on each.

\section{Clarifying Roles/Expectations}

Typical lists of recommendations for working effectively with a paraeducator begin with the statement that paraeducators need to understand clearly what is expected of them. McGrath et al. (2010) emphasize the importance of this clarification in relation to managing student behavior. Teachers need to express clearly which roles they intend to delegate to their paraeducator, and how they expect those roles to be carried out.

Calder and Grieve (2008) suggest that assigning certain administrative tasks to paraeducators is at the root of much confusion about what a paraeducator should and should not do. Some tasks clearly fall to the teacher (e.g., selection of curriculum content, interpretation of test data); some clearly belong under the definition of "support". But tasks that can be done by either teacher or paraeducator are grey areas which require clarification. Morgan and Ashbaker (2009) have emphasized the critical need for paraeducators to understand not only the extent of their roles, but also the limits-knowing what they should not do being almost as important as knowing what they should. McGrath et al. (2010) also warn against the dangers of a teacher delegating too much responsibility to a paraeducator: for example, a paraeducator who knows much more about a particular student than the teacher may feel she is the student's real teacher, possibly taking on curriculum planning and other decisions that should be made by the teacher.

A balance is critical as the teacher assigns responsibilities to the paraeducator but retains the decision-making appropriate to her training, legal obligations, and professional status. The teacher must give guidance and instructions for the paraeducator's daily tasks and carefully explain the rationale for those tasks and for her decisions relevant to them. Calder and Grieve (2008) note that all team members should clearly understand their own and others' roles, and they should agree on outcomes. For instance, a paraeducator who is assigned to support a particular student should understand clearly what that support is intended to achieve. Without such understanding, neither paraeducator nor teacher can clearly monitor and assess the effectiveness of that support and determine whether it could be applied more effectively elsewhere.

\section{Monitoring and Providing Feedback}

Another recommendation common in the literature is that teachers must monitor the support that paraeducators provide. In the early phases of the international discussion of collaborative work between teachers and paraeducators, Pickett (1999) identified "monitoring of paraeducators' work" as an essential element. In parallel with effective practice when teaching students, and for the same reasons, teachers must provide feedback to paraeducators.

Both students and paraeducators need to know whether they have "got it right" so that they become confident in their own effectiveness-reusing strategies the teacher has confirmed, and rejecting those the teacher has identified as unhelpful or counterproductive. French (2003) lists "performance monitoring and feedback" as one of the seven executive functions of teachers working with paraeducators. Likewise, Cobb (2007) asserts that training for paraeducators for instructional purposes must include "providing follow-up sessions and consultation" (p. 686). Deardorff et al. (2007), describing a training program for paraeducators working in early childhood special education programs serving rural and urban communities, also cite feedback to the paraeducator as a critical element for positive outcomes, regardless of the experience or education levels of the paraeducator.

In an Australian study, Howard and Ford (2007) found that "lack of feedback" was identified by paraeducators supporting students with disabilities in secondary level mainstream classrooms as one of the challenges of working in collaboration with teachers. This group of paraeducators had expressed general satisfaction with their jobs and pride in their contributions and achievements, but they did desire more support in this area.

\section{Providing On-the-Job Training for Paraeducators}

Wallace et al. (2001) list on-the-job training as one of the seven competency areas required of teachers directing the work of paraeducators. Under this heading they include providing opportunities for paraeducators to develop their skills; clarifying legal rights and responsibilities; and advocating for school/ district in-service training relevant to the paraeducator's daily work, particularly basic training in issues and strategies relating 
to students with disabilities. Hughes and Valle-Riestra (2008) report that the majority of the paraeducators involved in their research stated that on-the-job training was as important as attendance at workshops in adding to their knowledge and skills. The majority of their supervising teachers agreed with this.

\section{Interpersonal Skills}

In addition to these practical strategies for supervising and collaborating with paraeducators, the literature on teacherparaeducator collaboration includes development of various interpersonal skills. These include maintaining positive interpersonal relationships, developing a team ethos and approach, and valuing the paraeducator.

\section{Maintaining Positive Relationships}

Many authors (see for example Carnahan et al., 2009; Ghere \&York-Barr, 2007; Logan, 2006) have identified the importance of paraeducators receiving support from the teacher. This need for a supportive approach may supersede-or at least should precede-all other considerations; otherwise the sincerity of the teacher's efforts may be questioned, and the admittedly tricky negotiations involved in teachers directing paraeducators' work may be seriously undermined.

Appl (2006) expresses the importance of support for firstyear early childhood special educators in the phrase "teaching along with her” (p. 34). Riley (2010) goes so far as to suggest that "teachers should be open and willing to accept paraeducators as fellow education professionals and positive contributors to the classroom” (p. 11). Giangreco (2003) expresses this concept with a metaphor: teachers need to "change their role from gracious host to engaged teaching partner” (p. 50). Such partner status can avoid the potential awkwardness when veteran paraeducators may know more about classrooms (in terms of students, their families, and the school management system) than their newly-qualified "supervising" teachers—a situation which is all too common given the typical profile of paraeducators.

\section{Building an Instructional Team}

Gallagher et al. (2008) as well as Ghere and York-Barr (2007) identified a classroom team approach as a major factor in retaining paraeducators. Giangreco and Doyle (2007) attribute this to paraeducators feeling valued and respected if they are included in decision-making processes as members of the instructional team. Carnahan et al. (2009) recommend a systematic approach to team development that includes a shared philosophy, effective communication, regularly scheduled meetings, assessment of staff knowledge and experience, and a variety of in-service strategies-with ongoing performance assessments. Describing paraeducators in the Republic of Ireland, Logan (2006) observed how effective teams may be established through the same or very similar factors: effective communication and planning, shared understanding of the role and responsibilities of paraeducators and ongoing monitoring of the way in which support is provided". Hauwerwas and Goessling (2008) and Takala (2007) also emphasize the importance of joint planning.

Liston et al. (2009) highlight the need to seek the paraeducator's viewpoint. Brant and Burgess (2009) explain how this is done at London University's Institute of Education (UK), where teacher candidates complete a one-week internship as paraeducators in order to better appreciate the paraeducator's role. Brant and Burgess report that the teacher candidates came to better appreciate the challenges that face paraeducators, as well as the students and teachers in classrooms that cater for a wide variety of students needs. Perhaps more important to this discussion, they came to see the benefits of planning and collaborating with the classroom teacher and the critical need for open communication. These are all elements of teamwork that teachers practice to a greater or lesser extent with professional colleagues which are also conducive to effective teacherparaeducator collaborations in inclusive classrooms. DeVecchi and Rouse (2010) go so far as to suggest that truly inclusive schools and communities work to support the inclusion of not only students, but also of the adults who work in them.

\section{Enhancing Paraeducators' Experiences}

McGrath et al. (2010) chart ten particular challenges that face teachers when working with paraeducators, and provide recommendations for meeting these challenges and at the same time meeting the needs of the students. They offer a mnemonic for their recommendations, which are bulleted below:

$\mathrm{P}$ Prepare the paraprofessional from the beginning on his or her role;

A Assert your expectations in a helpful manner;

$\mathrm{R}$ Review frequently how things are going;

A Agree to work out any problems and support each other;

$\mathrm{P}$ Plan carefully the activities you wish the paraprofessional to conduct;

$\mathrm{R}$ Reinforce the paraprofessional for his or her many contributions and successes;

O Observe the paraprofessional frequently to ensure all is going well (McGrath et al., 2010: p. 6).

If a classroom teacher does not take the initiative in providing supervision, Ashbaker \& Morgan (2006) recommend that paraeducators should be proactive in seeking supervision in order that there may be a collaborative team approach to working in the classroom. Carnahan et al. (2009) are more specific in their recommendation that paraeducators be encouraged to provide feedback to teachers on shared philosophies and ways of working with students. We strongly acknowledge the contribution that paraeducators can make to the success of the classroom team.

\section{Conclusion}

Among researchers and professional educators, there is consensus over the practical strategies and approaches that facilitate collaborative working relationships between teachers and paraeducators; there is likewise recognition that this is not always an easy task. Wilson and Bedford (2008) refer to the "tensions between leadership and partnership" which teachers may experience. Veck (2009) argues that before paraeducators can contribute meaningfully to an inclusive classroom environment, teachers and administrators must examine the extent to which school practices tend to marginalize paraeducators and the students they support. Warnings have been issued:

"[T] here is a real danger that the rise of support staff will be equated in the minds of the community, and perhaps of educators, with-at best-the pathological development of a minority force to deal with an aberrant group of pupils, or at worst with the development of a second class teaching force to deal 
with second class pupils. That would turn an educational opportunity into a democratic disaster” (Kerry \& Kerry, 2003: p. 79).

What is abundantly clear is that training in how to work effectively with other adults (in particular paraeducators) cannot be an elective in a teacher education program-either general or special education. Kamman and Long (2010) describe-and recommend-an intensive induction training for special educators, ensuring teacher quality and retention and including knowledge and skills relating to collaborative work. Unfortunately, such training is not commonly available, and we still have a generation of teachers in classrooms around the world who have received little if any training in how to work effecttively with paraeducators. This being the case, we should be seeking early answers to the following questions:

1) What models exist of effective paraeducator employment and supervision (meeting the needs of students and adults alike)?

2) How can these models be adopted/adapted to meet the needs of a range of educational systems and provision without lessening their effectiveness?

3) How can teacher education best be involved with these models, to ensure cohesion and thorough preparation and professional development for both teachers and paraeducators?

Paraeducators can be of inestimable value to inclusive classrooms, but this value can only be truly realized when special educators take the initiative to be the manager of their own classrooms - when they take upon themselves the responsibility to work with paraeducators as fellow team members-in accordance with recommendations made here by those who have made it their study.

\section{REFERENCES}

Allen, K., Broughton, K., Ashbaker, B., \& Morgan, J. (1996). Teachers and paraeducators: Building stronger instructional teams. Utah Special Educator, 16, 17.

Allen, M., A., \& Ashbaker, B. Y. (2004). Strengthening schools: Involving para-professionals in crisis prevention and intervention. Intervention in School and Clinic, 39, 139-146.

doi:10.1177/10534512040390030201

Appl, D. (2006). First-year early childhood special education teachers and their assistants: "Teaching along with her." Teaching Exceptional Children, 38, 34-40.

Ashbaker, B. Y., \& Morgan, J. (2004). A legal memorandum: Quarterly law topics for school leaders. Reston, VA: National Association of Secondary School Principals.

Ashbaker, B. Y., \& Morgan, J. (2006). Paraeducators in the classroom. Needham Heights, MA: Allyn and Bacon.

Blacher, J., \& Rodriguez, T. (2007). Holding on to their kitestrings: Para-professional support in inclusive settings. Exceptional Parent, 37, 74-76.

Blair, J. (2002). Program finds new teachers in unexpected places: Schools. Education Week, 21, 9.

Blalock, G. (1991). Paraeducators: Critical team members in our special education programs. Intervention in School and Clinic, 36, 200214. doi:10.1177/105345129102600404

Brant, J., \& Lesley, B. (2009). Many hands make light work: How might acting as teaching assistant, help pre-service teachers develop their understanding of pupils' learning needs in London Secondary schools? London: University of London Institute of Education.

Broer, S. M., Doyle, M. B., \& Giangreco, M. F. (2005). Perspectives of students with intellectual disabilities about their experiences with paraeducator support. Exceptional Children, 71, 415-430.

Calder, I., \& Grieve, A. (2004) Working with other adults: What teachers need to know. Educational Studies, 30, 113-126. doi:10.1080/0305569032000159778

Carnahan, C. R., Williamson, P., Clarke, L., \& Sorensen, R. (2009). A systematic approach for supporting paraeducators in educational settings. Teaching Exceptional Children, 41, 34-43.

Causton-Theoharis, J., Giangreco, M. F., Doyle, M. B., \& Vadasy, P. F. (2007). Paraeducators: The "sous chefs" of literacy instruction. Teaching Exceptional Children, 40, 56-62.

Center for Research on Education: Diversity \& Excellence (2000). Examining latino paraeducators' interactions with Latino students. ERIC Clearing House on Languages and Linguists, EDO-FL-00-15.

Chopra, R. V., Sandoval-Lucero, E., Aragon, L., Bernal, C., De Balderas, H. B., \& Carroll, D. (2004). The paraeducator role of connector. Remedial and Special Education, 25, 219-231. doi:10.1177/07419325040250040501

Cobb, C. (2007). Training paraeducators to effectively work with all students. Reading Teacher, 60, 686-689. doi:10.1598/RT.60.7.10

Cortese, A. (2005). Take a good look at paraeducators. American School Board Journal, 192, 13.

Darden, E. C. (2009). Support staff and the law. American School Board Journal, 196, 32-33.

Deardorff, P., Glasenapp, G., Schalock, M., \& Udell, Tom. (2007). TAPS: An innovative professional development program for paraeducators working in early childhood special education. Rural Special Education Quarterly, 26, 3-15.

Defries, M. (2010). Teachers “misunderstand” how to use support staff. URL (last checked 4 February 2010)

http://www.nurseryworld.co.uk/news/981161/Teachers-misunderstan d-use-support-staff

DeVecchi, C., \& Martyn R. (2010) An exploration of the features of effective collaboration between teachers and teaching assistants in secondary schools. Support for Learning, 25, 91-99.

French, N. K. (1999). Paraeducators and teachers: Shifting roles. Teaching Exceptional Children, 32, 69-73.

French, N. K. (2001). Supervising paraeducators: A survey of teacher practices. Journal of Special Education, 35, 41-53.

French, N. (2003). Managing paraeducators in your school: How to hire, train, and supervise non-certified staff. Thousand Oaks, CA: Corwin Press.

Gallagher, P. A., Cynthia, O. V., \& Monda-Amaya, L. (2008). Perceptions of collaboration: A content analysis of student journals. Teacher Education and Special Education, 31, 12-20. doi:10.1177/088840640803100102

Ghere, G., \& York-Barr, J. (2007). Paraprofessional turnover and retention in inclusive programs: Hidden costs and promising practices. Remedial and Special Education, 28, 21-32. doi:10.1177/07419325070280010301

Giangreco, M. F. (2003). Working with paraeducators. Educational Leadership, 61, 50-53.

Giangreco, M. F., \& Doyle, M. B. (2007). Teacher assistants in inclusive schools. In L. Florian (Ed.), The SAGE handbook of special education (pp. 429-439). London: Sage. doi:10.4135/9781848607989.n33

Giangreco, M. F., Doyle, M. B., \& Suter, J. C. (2011). Constructively responding to requests for paraprofessionals: We keep asking the wrong questions. URL (last checked 11 June 2012). http://rse.sagepub.com

Giangreco, M. F., \& Broer, S. M. (2007). School-based screening to determine overreliance on paraeducators. Focus on Autism and Other Developmental Disabilities, 22, 149-158. doi:10.1177/10883576070220030201

Gursky, D. (2002). Recruiting minority teachers. Education Digest, 67, 28.

Hauerwas, L. B., \& Deborah P. G. (2008). Who are the interventionists? Guidelines for paraeducators in RTI. Teaching Exceptional Children Plus, 4, 1-13.

Hauge, J. M., \& Babkie, A. M. (2006). Develop collaborative special educator-paraeducator teams: One para's view. Intervention in School and Clinic, 42, 51-53.

Hoffman, L. and Sable, J. (2006). Public elementary and secondary students, staff, schools, and school districts: School year 2003-2004. Washington DC: National Center for Education Statistics. 
Howard, R., \& Ford, J. (2007). The roles and responsibilities of teacher aides supporting students with special needs in secondary school settings. Australasian Journal of Special Education, 31, 25-43. doi:10.1080/10300110701268461

Hughes, M. T., \& Valle-Riestra, D. M. (2008). Responsibilities, preparedness, and job satisfaction of paraeducators: Working with young children with disabilities. International Journal of Early Years Education, 16, 163-173. doi:10.1080/09669760701516892

Kamman, M. L., \& Suzanne, K. L. (2010). One district's approach to the induction of special education teachers. Journal of Special Education Leadership, 23, 21-29.

Kerry, C. A., \& Trevor, K. (2003). Government policy and the effective employment and deployment of support staff in UK Schools. International Studies in Educational Administration, 31, 65-81.

Lewis, S., \& McKenzie, A. (2009). Knowledge and skills for teachers of students with visual impairments supervising the work of paraeducators. Journal of Visual Impairment and Blindness, 103, 481494.

Liston, A. G., Nevin, A., \& Malian, I. (2009). What do paraeducators in inclusive classrooms say about their work? Analysis of national survey data and follow-up interviews in California. Teaching Exceptional Children Plus, 5, 2-17.

Logan, A. (2006). The role of the special needs assistant supporting pupils with special educational needs in Irish mainstream primary schools. Support for Learning, 21, 92-99. doi:10.1111/j.1467-9604.2006.00410.x

Mastropieri, M. A. (2001). Is the glass half full or half empty? Challenges encountered by first-year special education teachers. Journal of Special Education, 35, 66-74. doi:10.1177/002246690103500201

McGrath, M. Z., Johns, B. H., \& Mathur, S. R. (2010). Empowered or over-powered? Strategies for working effectively with paraeducators. Beyond Behavior, 19, 2-6.

Morgan, J., \& Ashbaker, B. Y. (2001). A teacher's guide to working with paraeducators and other classroom aides. Alexandria, VA: Association for Supervision and Curriculum Development.

Morgan, J., \& Ashbaker, B. Y. (2009). Supporting and supervising your teaching assistant. London: Continuum.

NCES (2007). The condition of education 2007. URL (last checked 11
June 2012). http://www.nces.ed.gov/pubs2007/2007064.pdf

Patterson, K. B. (2006). Roles and responsibilities of paraeducators: In their own words. Teaching Exceptional Children Plus, 2, 1.

Pickett, A. L. (1999) Strengthening and supporting teacher/providerparaeducator teams: Guidelines for paraeducator roles, supervision, and preparation. New York: National Resource Center for Paraeducators.

Pickett, A. L. (2002). Paraeducators: The evolution in their roles, responsibilities, training, and supervision. Impact, 15, 2-3.

Riley, G. (2010). Working with a paraeducator. New Teacher Advocate, $17,10-11$.

Roberts, C. (2010). A positive partnership. URL (last checked 10 May 2012). www.tda.gov.uk/professionalteacher_feb2010_tda0785.pdf

Rueda, R., \& Lilia, M. D. (2002). Apprenticeship for teaching: Professional development issues surrounding the collaborative relationship between teachers and paraeducators. Teaching and Teacher Education, 18, 503-521. doi:10.1016/S0742-051X(02)00013-6

Rueda, R. S., \& Lilia, M. (2000). Apprenticeship for teaching: Professional development issues surrounding the collaborative relationship between teachers and paraeducators. Washington DC: Center for Research on Education, Diversity \& Excellence.

Takala, M. (2007). The work of classroom assistants in special and mainstream education in Finland. British Journal of Special Education, 34, 50-57. doi:10.1111/j.1467-8578.2007.00453.x

Veck, W. (2009). From an exclusionary to an inclusive understanding of educational difficulties and educational space: Implications for the learning support assistant's role. Oxford Review of Education, 3, 4156. doi:10.1080/03054980701782031

Wallace, T., Shin, J., Bartholomay, T., \& Stahl, B. J. (2001). Knowledge and skills for teachers supervising the work of paraeducators. Exceptional Children, 67, 520-533.

Walsh, J. M., \& Jones, B. (2004). New models of cooperative teaching. Teaching Exceptional Children, 36, 14-20.

Wilson, E., \& Bedford, D. (2008) New partnerships for learning: Teachers and teaching assistants working together in schools-The way forward. Journal of Education for Teaching, 34, 137-150. doi:10.1080/02607470801979574 